Драгана Керкез

Бојана Сабо

Филолошки факултет

Универзитет у Београду

draganakerkez@hotmail.com

bojana.sabo@gmail.com

https://doi.org/10.18485/ai_knjiz_u_prevodu.2019.ch4

$81^{\prime} 255.4$

821.161.1.09-31 Водолазкин, Е. Г.

\title{
ПРЕВОД РОМАНА ЛАВР Ј. ВОДОЛАСКИНА НА СРПСКИ ЈЕЗИК
}

Рад се бави преводом на српски језик романа Лавр J. Водоласкина који је изазвао велике полемике у нашој јавности, због тога што је приликом превода изостао карактеристичан за аутора и наведено дело стил.

Кључне речи: превод књижевноуметничког дела, наслов, поднаслов, ојконими, архаизми, реалије.

0.0. Један од највећих књижевних догађаја у Русији 2012/2013. године била је појава романа Јевгенија Водоласкина Лавр: чим се 2012. појавио на полицама руских књижара овај роман је привукао велику пажњу како читалачке публике, тако и стручне јавности (своје признање стручна јавност је изразила у виду двеју књижевних награда (Велика књига (рус. Больщая книга) и Јасна Пољана (рус. Ясная Поляна), којима је наредне, 2013, ово Водоласкиново дело било овенчано). ${ }^{1}$

1 Осим ове две награде, овај роман је 2016. добио и награду која носи име М. Горког и додељује се у Италији. 
Ни љубитељи лепе речи у Србији нису дуго чекали овај роман Ј. Водоласкина, будући да се превод на српски језик појавио већ 2013. године (превод је урадила Радмила Мечанин, а издала га је Издавачка кућа „Драслар Партнер”).

Предмет анализе у овом раду биће управо овај превод романа Лавр, тачније анализа неких елемената превода: наслова, поднаслова те одређених лексичких компоненти.

01. Превод књижевноуметничког дела представља посебну врсту преводилачке делатности која са техником превода стручних текстова ${ }^{3}$ поседује како заједничке, тако и разликовне елементе. С једне стране, према правилном запажању руског хиспанисте и теоретичара превода В. С. Виноградова, циљ превода није подешавање текста у односу на нечију перцепцију, већ очување садржаја, функције, стилогених, стилистичких, комуникативних особености оригинала (Виноградов 2001: 20). С друге стране, књижевноуметнички текст поседује низ особености у односу на остале функционално-стилске типове текста, међу којима се као доминанта издваја уметничко-естетска или поетска функција, услед чега се превод књижевноу-

2 Ваља рећи да су читаоци у Србији већ имали прилике да се упознају са Е. Водоласкиним као писцем. Године 2010. у преводу Југославке Миљковић-Катић појавио се Водоласкинов роман-првенац Отимане Европе. Превод на српски језик другог по реду романа који је написао Водоласкин (Соловјов и Ларионов) такође је резултат труда Југославке Миљковић-Катић (роман се у Русији појавио 2009. а превод на српски је изашао 2014). Роман Авијатичар на српском језику се појавио 2018. године (на руском је изашао 2016), а превод је урадила Радмила Мечанин.

3 У терминологији В.Н. Комисарова - информативни превод (Комисаров 1995: 20). 
метничког дела може сматрати самосталним делом које је саздано на језику превода (Комиссаров 1990: 95). На основу реченог јасно проистиче закључак да је преводилац књижевноуметничког дела стално суочен са двама, у извесном смислу супротстављеним начелима: начелом прецизности и начелом креативности (Керкез 2018: 242).

Приликом анализе превода романа Лавр на српски језик руководићемо се управо наведеним начелима.

1. Један од посебних изазова за сваког преводиоца јесте превод наслова дела. Наслов је оно прво са чим се читалац сусреће када говоримо о неком књижевном делу. Осим своје функције да заинтересује читаоца, наслов, као што је то општепознато, има кључну позицију у односу на садржину текста, будући да управо он представља онај микроисказ који помаже читаоцу у идентификацији топика или теме дела, што није ништа друго до крајње уопштено исказана фабула ${ }^{4}$ (Еко 2007: 357). Осим тога, наслов је, што се на анализираном примеру веома добро види, својеврсна ауторска интерпретација текста као и одраз ауторове слике света (Николина 2003: 166-167).

За наслов романа Водоласкин је одабрао име Лавр, последње од четири имена главног јунака. Рођен на дан Светог Арсенија Великог, главни јунак добија име свог небеског заштитника и носи га све до краја другог дела романа ${ }^{5}$ током ког од детета израста у младог тра-

4 Термин 'фабула' користимо, следећи у томе У. Ека, као истозначан термину 'сиже'.

5 Роман садржи пет делова: Пролегомену, Књигу познања, Књигу одречења, Књигу пута и Књигу смирења. Важно је рећи да смо овде дали своје предлоге превода трећег и петог дела (Књига одречења и Књига смирења), али се овом приликом на томе нећемо заустављати. 
вара и исцелитеља. У трећем делу романа главни јунак прихвата своју кривицу за смрт вољене жене кроз јеванђељску поруку „Покајте се!” (уп. МТ 4:17, МК 1:15) и носи име Јустин, а у четвртом он је монах, лекар, прозорљивац Амвросије. У последњем делу романа главног јунака видимо као схимника који је успео да победи страсти у себи, да стекне смирење - управо због тога он добија име Лавр (краћи облик имена Лаврентије), уколико прихватимо је етимологија имена следећа: грч. Lauros: лат. laurus (дрво) - ловор (Суперанская 2005: 141).

Као што се из наведеног може закључити, имена главног јунака немају само номинативну функцију, већ и допунско конотативно значење: свако од њих на неки начин представља својеврстан хронолошки запис унутарњег стања главног јунака. Оваква ситуациона условљеност имена главног јунака не само што потврђује давно изречену тврдњу да имена у књижевном делу никако не могу имати само номинативну функцију (Тынянов 2002: 186-187), ${ }^{6}$ већ умногоме доприноси интензивнијем доживљају различитих етапа у животу јунака.

Име Лавр постоји у српском језику, али се среће крајње ретко. Колико је нама познато, једино као име једног од двојице браће ранохришћанских мученика: света браћа Флор и Лавр. Међутим, на основу краће анкете коју смо спровели ${ }^{7}$ дошли смо до закључка да

6 «В художественном произведении нет неговорящих имен. В художественном произведении нет незнакомых имен. Все имена говорят. Каждое имя, названное в произведении, есть уже обозначение, играющее всеми красками, на которые только оно способно. Оно с максимальной силой развивает оттенки, мимо которых мы проходим в жизни.»

7 Број респодената је невелик: нешто преко 20. Међутим, имајући у виду чињеницу да је група испитаника циљно бирана (сви испитаници су факултетски образовани, а већина њих су филолози), а да је само један респодент препознао облик као постојећи антропоним и повезао га са реалном личношћу, 
је било оправдано упознати читаоца са чињеницом да име Лавр није плод пишчеве маште, већ постојећи антропоним: нпр. фуснотом при првом помињању имена у самом тексту романа или пак другачијим решењем корица књиге. ${ }^{8}$

Овакав поступак јасније би нагласио својеобразност темо-рематског односа наслова и текста: на почетку наслов има функцију теме док је текст у односу на њега рема. На крају процеса читања однос наслова и текста дела се мења, тј. наслов више нема функцију теме (номинативну фукцију), већ се трансформише у рему (Маслова 1997: 25 према Петровна 2016).

2. За разлику од наслова, који је обавезна компонента књижевног дела, један од факултативних елемената тзв. оквира дела јесте поднаслов који је својеврсни оријентир у односу на семантичке кодове које је неопходно активирати у читаочевој свести (уп. Абилова 2015: 66).

J. Водоласкин свом делу даје поднаслов „Неисторијски роман"9 и на тај начин усмерава свог читаоца да

мишљења смо да се резултати ове анкете могу узети у обзир, макар као нека врста сигнала.

Осим имена Лавр, показало се да је и име Устин за наше респоденте тешко препознатљиво. Наиме, Устин у руском језику представља облик имена Јустин а у речнику Суперанске поред њега стоји квалификатор „разг” (Суперанская 2005: 245). Узимајући у обзир значење имена ('онај који је спреман на подвижнички живот'), као и чињеницу да је Водоласкин врло пажљиво бирао свако од четири имена свог јунака, сматрамо да би облик Јустин био правомерније преводилачко решење.

8 «Иллюстрация на обложке книги - это заблаговременная выработка образного ряда текста для удобства восприятия произведения читателем и правильной интерпретации произведения.» (Љадова 2017: 2)

9 Поједини аутори повезују роман Лавр, између осталих, и са жанром историјског романа или пак у њему проналазе елементе карактеристичне за овај жанр (Махинина, Сидорова 2016; Черный 2017). 
тражи и препознаје у роману реалне људи и догађаје који су записани у времену. Нпр. однос главног јунака и медведа ${ }^{10}$ читаоца ће подсетити на моменте из житија Светог Сергија Радоњешког (Рождественский 2011) и Светог Серафима Саровског (Шевкунов 2018). У „КњИзи одречења" главни јунак одбацује своје име, али се и одриче себе самог ${ }^{11}$ да би узео име своје упокојене супруге што директно асоцира на Свету Ксенију Петербуршку која се после кончине мужа одрекла свог имена и оденула у мужевљево рухо (Маркова 2014). Осим наведеног, у роману постоји још не тако мали број сцена али и ликова које проналазимо у житијама других светитеља (нпр. јуродиви Карп у читаочевој свести буди асоцијацију на житије блаженог Симона чудотворца Јуревецког).

Преводилац, вођен садржајем текста, нуди следеће решење - „Животопис”. Премда је и овакво преводилачко решење прихватљиво, мишљења смо да би се чувањем, тако да кажемо, алузивног поднаслова „Неисторијски роман” читалац адекватније упутио на чињеницу да се главни јунак може посматрати као кумула-

10 «Приходя к Лавру, медведь жаловался на морозы, отсутствие питания и свою общую неустроенность. В самые холодные дни Лавр пускал его в пещеру погреться, призывая гостя не храпеть во сне и не отвлекать его от молитвы. Само же их соседство Лавр предлагал ему рассматривать как меру временную. В самом конце декабря медведь все-таки нашел себе берлогу, и Лавр вздохнул с облегчением.» (ЕВ: 411-412)

11 «Как тебя зовут?

Вот как образуются звуки, подумал Арсений.

Как тебя зовут, снова спросил рот.

Он произнес три слова раздельно, словно не доверял слуху лежащего.

Устин, едва слышно сказал Арсений.

Устин. Лицо к кому-то обернулось. Его зовут Устин. Что ти приключися, Устине?» (ЕВ: 164-165) 
тивни лик више православних светитеља, те да самим тим у основи одређених пасажа леже реални догађаји из њихових живота (без обзира на то што главни јунак нема свог реалног прототипа, нити је за основу романа узет неки конкретан историјски догађај), као и на, што је можда још важније, на свевременост и ванвременост главне теме романа (Калдыбекова 2015).

3. Осим жанровске еклектичности, разнородан је и језик романа Лавр: $:^{12}$ писац је саздао своје дело служећи се савременим и староруским језиком тако да се за овај роман може рећи у неку руку да је билингвалан. При томе, није неважно нагласити да савремени руски језик у роману одликује функционална разноврсност: поред неутралне лексике среће се и она стилски маркирана попут израза својствених сленгу или доњем регистру колоквијалног језика, нпр. Ах mы ё-моё... (ЕВ: 158). С друге стране, староруски језик у роману не само што је инкрустриран елементима старословенског језика, већ су видљиве и ауторове интервенције.

У даљем тексту нашег рада ми ћемо се зауставити само на појединим лексичким решењима које нам је преводилац понудио и на преводу претериталних конструкција.

3.1. Кад је реч о лексици, прво ћемо обратити пажњу на превод оних лексичких јединица помоћу којих писац квалификује професионалну делатност свог главног јунака.

12 О роману Лавр до сада је написан не тако мали број радова, међутим оних који се баве језичким особеностима овог дела нема пуно. У том невеликом броју лингвистичких студија посебно место заузима монографија Ј. Малчивецке и Т. Попове која је посвећена архаизмима (Мальчивецкая, Попова 2017). 
У првом, уводном делу романа (Пролегомени) читамо:

«У него было также два прозвища. Одно из них - Рукинец - отсылало к Рукиной слободке, месту, где он появился на свет. Но большинству этот человек был известен под прозвищем Врач, потому что для современников прежде всего он был врачом.» (ЕВ: 7)

\section{И нешто даље}

«Грань между врачом и знахарем была в ту эпоху относительной.» (ЕВ: 7)

Преводилац се одлучује за следеће преводилачко решење:

„Он је имао и два надимка. Један од њих - Рукинец - асоцирао је на Рукину Слободицу, место у коме се родио. Али, већина је тог човека знала по надимку Врачар, зато што је за савременике био, пре свега, лекар." (JB: 7)

И

„Граница између врачара и видара у то доба је била релативна." (JB: 8)

Из наведеног одломка нас ће интересовати три речи: врач, знахарь и слободка. Прве две лексеме део су синонимског низа који Водоласкин користи ради именовања професије свог главног јунака (поред наведених, срећу се још лексеме иелитель и лекарь) и припадају корпусу активног лексичког слоја савременог руског језика и, према лексикографским подацима, стилски су неутралне. Лексема слободка припада архаизмима, тј. пасивном фонду лексикона. 
3.1.1. Лексема врач у савременом руском језику има значење лекар (Ожегов 1996: 99), а у истом значењу среће се још у у Остромировом јеванђељу (према Срезневский 1893: 315).

Именица знахарь се у руском језику појављује тек у 15. веку и током процеса развоја руског језика од значења 'оног који зна шта да чини' (Срезневский 1983: 993) и добија значење самоуког лекара који лечи на примитиван начин, користећи се, најчешће, враџбинама (Ожегов 1996: 227).

Када је у питању српски језик, у Вуковом речнику наспрам посматране леме налазимо 'погађач, гатар'. Савремени лексикограф даје следећу лексикографску дескрипцију: „врач, врача м (мн. врачеви (врачи) 1. а. По народном празноверном схватању човек натприродне моћи који може да утиче на неке природне појаве и на људску судбину, чаробњак, маг; код примитивних народа свештеник који се стара о култним обредима. б. нар. онај који лечи народним лековима и враџбинама, народни лекар. 2. онај који врачањем погађа прошлост и прориче будућност, врачар, гатар" (МС 2007: 160), а за семантизације лексема а) врачар и б) видар гласе: а) „онај који врача, који се бави врачањем, гатар” (MC 2007: 160) и б) „онај који вида, лечи ране, исцелитељ” (МС 2007: 134).

На основу увида у лексикографски материјал може се извести закључак да би као еквивалент руске лексеме врач правомерније било одабрати неутралну лексему лекар или видар, ${ }^{13}$ док би српска лексема врачар била адекватнији еквивалент руској именици знахарь.

13 У прилог реченом навешћемо податак да је Вук у Правитетьствујушчем совјету напоредо употребљавао лексеме видар и лекар (Драгичевић 2018: 131). 
3.1.2. Слободка је наредна лексема о којој ћемо рећи пар речи. Лексема је веома занимљива: с једне стране, може се посматрати као реалија и историзам, будући се у роману употребљава као језички знак за врсту насеља које више не постоји. У средњовековној Србији имамо називе за различите категорије становништва. Целокупно зависно становништво носило је назив себари, а у њих су спадали меропси (зависни сељаци), Власи (зависни сточари), отроци (нека врста робова), маисторије (зависне занатлије), сокалници (сталеж нејасних права и обавеза) (Шаркић 2011: 59). Наспрам овог богатства за именовање различитих социјалних слојева, за насеобине у којима они живе у свим радовима које смо консултовали користи се апелатив село. С друге стране, облик именице који Водоласкин употребљава преставља деминутив изведен од облика свобода, а као што знамо, употреба деминутива у руском и српском језику битно се разликују.

Именицу слобода речници бележе као историзам или архаизам. Међутим, неопходно је рећи да се овај апелатив и данас среће као саставни део ојконима, првенствено (али не само) комонима (уп. Гомырова 2014: 209; Брумистрова 2014: 234; Поспелов 2008: 259, $364,410)$. Тако нпр. према резултатима истраживања E.M. Поспелова од старих термина у топонимији Московске области најприсутнији је апелатив слобода (Поспелов 2008: 35).

Потврду древности ове именице налазимо у најстаријим руским очуваним писаним споменицима: Срезњевски у свом речнику дату речничку одредницу илуструје, између осталог, и примерима из Лаврентјевског летописа (Срезневский 1903: 278). Исти речник бележи и лексему слободка. 
У средњовековној Русији датим апелативом именоване су ослобођене од уплате намета сеоске настамбине, које су крајем 18. века полако почеле ишчезавати или се стапати са другим селима или градовима.

На сличан начин дата лексема се семантизује и у речнику В. Даља ('село слободних људи' и 'село тик уз град'), где је већ маркирана као архаизам (Даль 1998: 221). Савремени речник руског језика такође бележи посматрану лексему као полисемичну, али се прво значење одређује као историзам, док се као архаична наводе два значења: 'велико трговачко село' и 'насеље тик уз град, предграђе' (Ожегов 1996: 718).

Водоласкин у свом роману користи облик слободка, и то чак 58 пута, а по први пут читалац на ову реч наилази већ на самом почетку, у Пролегомени:

«У него было также два прозвища. Одно из них - Рукинец - отсылало к Рукиной слободке, месту, где он появился на свет». (ЕВ: 7)

У време када се дешава радња у роману (15. век), Рукина слободка је постојала при Кирило-Белојезерском манастиру ${ }^{14}$, те из тога можемо закључити да је пред нама реалија, при томе реалија која је била име за део стварности који више не постоји.

Када се сусретне са реалијом у тексту преводилац се истовремено сусреће са двема потешкоћама. Прва потешкоћа представља непостојање одговарајућег

14 У Русији и данас постоје и Кирило-Белојезерски манастир и село Рукино, а налазе се у Кириловском округу Волгодске области. Етимологија ојконима се везује за име земљепоседника Руке Ивана који је живео у тим крајевима негде у другој половини 14. века. (Мальчивецкая, Попова 2017: 88) 
еквивалента (када одсуство денотата у култури језика на који се преводи једнозначно повлачи за собом и одсуство одговарајућег језичког знака). ${ }^{15}$ Друго, поред предметног значења, преводилац мора пренети и конотацију под којом овде подразумевамо национални колорит превођене лексеме (Влахов, Флорин 1980: 80).

О преводу реалија заиста постоји веома богата литература (имамо у виду пре свега литературу на руском језику $)^{16}$, те ћемо овде, пре него што се поново вратимо лексеми слободка, само навести основне начине њиховог преношења: транскрипција (транслитерација), хипо-хиперонимски превод (генерализација), функционална замена, описан превод и калкирање.

Дакле, вратимо се сад лексеми слободка. У српском преводу романа Лавр читамо:

„Он је имао и два надимка. Један од њих - Рукинец - асоцирао је на Рукину Слободицу, место у коме се родио.” (JB: 7)

Чини нам се да је, вођен етимологијом речи преводилац као најадекватније решење видео српски аналог

15 Да то не мора бити тако потврђује чињеница да су поједине реалије из различитих језика лако препознатљиве говорницима српског језика (наравно, ово би се односило и на говорнике других језика), будући да те реалије имају интернационални карактер. Неке од таквих реалија са временом постану и део лексичког фонда неког другог језика. Када говоримо о руско-српским језичким односима и о реалијама које су из руског ушле у српски лексикон, таквих речи нема пуно али их има, нпр. на стр. 1165. Речника српског језика (МС 2007) налазимо речничку одредницу самовар.

16 Пошто је литература на руском заиста веома богата, овде ћемо споменути само чувену монографију Влахова и Флорина чији је читав први део посвећен реалијама (укупно 174 стране) (Влахов и Флорин 1980) и упутити на саjт elibrary.ru, на ком постоји преко 1200 нотираних публикацију на дату тему. 
руске лексеме свобода, тачније деминутив дате лексеме. Уколико бисмо прихватили тезу да је етимологија речи довољно добро упориште за одабир лексеме слобода као преводног еквивалента у српском и занемарили чињеницу да је пред нама реалија, ипак остаје питање употребе деминутива.

Руски језик је одиста веома богат различитим језичким средствима за изражавање емоција, што се може посматрати као одраз наглашене емотивности Руса (уп. Вежбицкая 1999: 34-34). Међу тим средствима су и деминутиви.

Према Ј. Л. Воротњикову, деминутиви у руском језику могу вршити три функције: 1. денотативну (деминутивом се маркира величина предмета или степен изражености особине); 2) експресивно-емоционалну (говорно лице изражава свој однос према саговорнику или актуелној ситуацији); 3) конотативну (у неофицијелном разговору када помоћу деминутива говорно лице успоставља блискији однос са саговорником) (Воротников 1988).

Све три наведене функције деминутиви имају и у српском језику (у нашој литератури разликују се деминутиви и хипокористици). ${ }^{17}$ Међутим, без обзира што деминутиви и у српском језику могу имати све три функције, деминутиви именица које означавају неживо у експресивно-емоционалној и конотативној функцији се релативно ретко користе (нпр. у конотативној функцији најчешће када неко позива свог саговорника на кафииу, ракијииу, пићение). ${ }^{18}$

17 „Хипокористичност у садржај деминутива уноси компоненту симпатије, милоште, као израз говорникове наклоности и нежности како према појму на који се указује, тако и према целокупној комуникативној ситуацији.” (Јовановић 2010: 27)

18 О разлици употребе деминутива у руском и српском већ је писано (види нпр. Матијашевић 1999). 
Када је пак у питању превод наведеног примера, с наше тачке гледишта, можда би адекватније преводилачко решење било послужити се транслитерацијом дате речи у српски (слободка), а потом даље у тексту уместо речи место употребити хипероним село: Један од юих, Рукинеи, асоцирао је на Рукину слободку, село у ком се родио.

У предлогу превода реченице који смо овде навели, уочава се још једна, наизглед мала, али суштински битна разлика. Реч слободка Водоласкин доследно пише малим словом, што значи да лексема није саставни део ојконима, ${ }^{19}$ тако да је то ваљало сачувати и у преводу.

4. На крају ћемо само поновити да циљ овог рада није била критика постојећег превода, већ покушај да се још једном сагледају неки од механизама и путева који би преводиоцу омогућили да задовољи како начело прецизности, тако и начело креативности.

А што је језик и мисао којим се служи аутор сложенији, преводиоцу је све теже да подједнако задовољи та начела.

А преводити роман Лавр који, како је то једном приликом правилно приметио ђакон Ненад Илић, представља топлу причу о тражењу пута, о греху и искупљењу, о жртвовању себе и налажењу племените мере служења другим, заиста није било лако, будући да аутор није само написао староруским језиком одређене

19 Нарицательные существительные в составных географических названиях пишутся с прописной буквы, если они употреблены не в прямом значении и называют объект условно, например: Белая Церковь (город) [...] Но Чистые пруды (улица в Москве, на которой имеются пруды), Кузнеикий мост (улица в Москве, часть которой когда-то занимал мост через реку Неглинку), Никитские ворота (когда-то ворота в стене, окружавшей Москву), (Розенталь 2005: 20). 
делове књиге, већ је користећи се различитим лексичким, синтаксичким архаизмима реконструисао и читав средњовековни поглед на свет.

\section{Скраћенице}

MT: Свето Јеванђеље по Матеју

МК: Свето Јеванђеље по Марку

MC: Речник српског језика

\section{Извори}

Водолазкин, Евгений. Лавр. Москва: АСТ, 2014.

Водоласкин, Јевгеније. Лавр. Београд: Драслар Партнер, 2013. Свето Писмо. Нови Завјет. Београд: Свети архијерејски синод, 1997.

Абилова, Ф. А. «Функции подзаголовка в романах уэссекского цикла. Т. Гарди».

Международный научно-исследовательский журнал. №3 (34) (2015): 66-67. Veb. 29.06.2019.

Бурмистрова, Т.А. «Структура и содержание лексико-семантической группы наименований населенных пунктов (по данным источников лингвистического и справочного характера)». Мир науки, культуры, образования. № 3 ( 2014). Veb. 28.06.2019.

Вежбицкая, Анна. Язык. Культура. Познание. Москва: Русские словари. 1996.

Виноградов, Венедикт Степанович. Введение в переводоведение (общие и тексические вопросы). Москва: Издательство института общего среднего образования РАО, 2001. Влахов, Сергей. Флорин, Сидер. Непереводимое в переводе. Москва: Международные отношения, 1980.

Воротников Ю. Л. «Милое и малое», Русский язык в школе. № 6 (1988): 62-66.

Гомырова Ю. Ю . «Географические термины, обозначающие населенные пункты, в комонимии Ярославской обла- 
сти». Ярославский педагогический вестник. Том I (Гуманитарные науки). № 4 (2014). Veb. 25.06. 2019.

Даль, Владимир Иванович. Толковый словарь живого великорусского языка: В 4 т. / Вступ. ст. А.Н. Тихонова; Ред. И.А. Бодуэна де Куртенэ. - Репр. изд. - Москва: Цитадель, 1998.

Драгичевић, Рајна. Српска тексика у прошлости и данас. Нови Сад: Матица српска, 2018.

Калдыбекова, Ж.А. «Художественное время в романе Е. Водолазкина Лавр». Наука и современность. № 37-1 (2015): 103-107.

Керкез, Драгана. „Превод романа Корени на руски језик”. Книжевно дело Добрице Ћосића. Зборник радова. Београд: Филолошки факултет у Београду, 2018. 241 - 254. Штампано.

Козьма, Маргарита Петровна. «Заглавие как способ декодирования художественного текста». Филологические науки. Вопросы теории и практики. №10-1 (64). (2016). Veb. 26. 06. 2019.

Комиссаров, Вилен Наумович. Теория перевода (лингвистические аспекты): Учебник для институтов и факультетов иностранных языков. Москва: Высшая школа, 1990.

Лядова, Елена Анатольевна. Оформление книги как способ привлечения иелевойаудитории. 2107. Veb. 25.04.18.

Мальчивецкая, Юлия. Попова, Татьяна. Редкая и устаревшая лексика в романе Е. Водолазкина «Лавр». 2017. Veb. 08.06.2019.

Маркова, А.А. Святая блаження Ксения Петербургская. Москва: Благовест, 2014.

Матијашевић, Јелка. „О аксиолошким параметрима у деривацији”. Славистика III (1999): 168-174.

Махинина Наталия Георгиевна, Сидорова Марина Михайловна. «Историческое время в романе Е. Водолазкина «Лавр» (к постановке проблемы)». Вестник ТГГПУ. №2 (44) (2016). Veb. 20.06.2019.

Николина, Наталья Анатольевна. Филологический анализ текста: Учеб. пособие для студ. высш. пед. учеб. заведений. Москва: Издательский центр «Академия», 2003. 
Ожегова, Сергей Иванович. Шведова, Наталия Юльевна. Толковый словарь русского языка. Москва: Азъ, 1996.

Поспелов, Евгений Михайлович. Географические названия Московской области: топонимический словарь. Москва: АСТ: Астрель, 2008.

Речник српског језика. Мирослав Николић (ур.). Нови Сад: Матица српска, 2007.

Рождественский, Никон (архиепископ). Житие и подвиг пребодобного Сергия, игумена радонежского и всея России чудотвориа. Сергиев Посад. Свято-Троицкая Сергиева лавpa, 2014.

Розенталь, Дитмар Эльяшевич. Справочник по правописанию и литературной правке. Под ред. И.Б. Голуб.10-ое Издание. Москва: Айрисс-пресс.

Срезневский, Измаил Иванович. Материаль для словаря древнерусского языка по письменным памятникам. Т. 1-3. [Из. и дополнения А - М]. Вып. 1. Р - СТЕП / Труд И.И. Срезневского. - СПб. : Отд-ние рус. яз. и словесн. Имп. AH, 1903. Veb. 29.06.2019.

Суперанская, Александра Васильевна. Современный словарь личных имён: Сравнение. Происхождение. Написание. Москва: Айрис- пресс, 2005.

Тынянов Ю. Литературный факт. Литературная эволюиия. Москва: АГРАФ, 2002.

Черный, Игорь Вительевич. «Роман Е.Водолазкина Лавр как литературное житие /И.В.Черный» Матеріали I Міжнародної науково-практичної конференції Актуальні питання богослов'я та історії церкви: до 1900-річчя преставлення св. апостола і євангеліста Іоанна Богослова. Харків: ХДС, 2017. - С.255-257.

Эко, Умберто. Роль читателя. Исследования по семиотике текста / Перев. с англ. и итал. С. Д. Серебряного. Санкт-Петербург: «Симпозиум», 2007.

Шаркић, Срђан. „Маисторије, сокалници и сеоски попови”. Зборник радова Правног факултета у Новом Саду, 1(2011): 59-67. Veb. 25.06. 2019.

Шевкунова, Тихон (митрополит). Батюшка Серафим. Москва: Сретенский монастырь. 2016. 
Dragana Kerkez

Bojana Sabo

\section{TRANSLATION OF J. VODOLAZKIN'S NOVEL LAVR INTO THE SERBIAN LANGUAGE}

The paper deals with translations into Serbian of novel Laurus of the famous Russian writer E. Vodolazkin. Special attention was paid to the translation of the novel Laurus, which caused great controversy in our public, because the translation lacked characteristic for the author and the stated work style. 